\title{
Pengaruh Aromaterapi Lavender, Relaksasi Otot Progresif dan Guided Imagery terhadap Kecemasan Pasien Pre Operatif
}

\author{
Ririn Sri Handayani ${ }^{1}$, El Rahmayati ${ }^{2}$ \\ ${ }^{1,2}$ Jurusan Keperawatan, Politeknik Kesehatan Tanjungkarang, Indonesia \\ Email: xririnx@gmail.com
}

\begin{abstract}
Effect of Lavender Aromatherapy, Progressive Muscle Relaxation and Guided Imagery on Pre Operative Patient Anxiety. An anxious condition of the patient will affect the function of the body before surgery. High anxiety can affect the physiological function of the body which is characterized by an increase in pulse and respiration frequencies, a shift in blood pressure and temperature, relaxation of smooth muscles in the bladder and intestines, cold and moist skin, increased respiration, pupillary dilation, and dry mouth. This condition is very dangerous for the patient's condition so that an operation can be canceled or postponed. Other consequences, the length of patient care will be longer and cause financial problems. The aim of the study was to determine the effectiveness of lavender aromatherapy, progressive relaxation, and guided imagery to reduce preoperative anxiety in patients. The research design used was Quasi-experimental with Pre post-test design or one group before and after. The study population was adult patients who would undergo elective surgery at dr. H. Abdul Moeloek Lampung Province. The large calculation of samples taken using the Sample Size Calculator For Designing Clinical Research for one group before after study for the paired t-test statistical test. By setting Alpha 0.01, Betha 0,100, Effect Size 0,500 and Standard Deviation 1.00 so that the number of samples used is equal to 60 people. The sampling technique uses simple random sampling method. The results of this study concluded that lavender aromatherapy, progressive muscle relaxation, and guided imagery were effective in reducing preoperative anxiety (mean score before intervention 7.67 (SD 7.890), score after intervention 4.05 (SD 5.806)) with $\rho$ value 0.000 . Researchers suggest that lavender aromatherapy, progressive relaxation, and guided imagery can be used as standard interventions in preoperative anxiety diagnosis of patients' anxiety by nurses, this therapy should be done several times until the patient will enter the operating room and this therapy can be taught to nursing students as an action to overcome preoperative anxiety.
\end{abstract}

Keywords: Guide imagery, Lavender, Relaxation, Anxiety

Abstrak: Pengaruh Aromaterapi Lavender, Relaksasi Otot Progresif dan Guided Imagery terhadap Kecemasan Pasien Pre Operatif. Keadaan cemas pasien akan berpengaruh kepada fungsi tubuh menjelang operasi. Kecemasan yang tinggi, dapat mempengaruhi fungsi fisiologis tubuh yang ditandai dengan adanya peningkatan frekuensi nadi dan respirasi, pergeseran tekanan darah dan suhu, relaksasi otot polos pada kandung kemih dan usus, kulit dingin dan lembab, peningkatan respirasi, dilatasi pupil, dan mulut kering. Kondisi ini sangat membahayakan kondisi pasien, sehingga dapat dibatalkan atau ditundanya suatu operasi. Akibat lainnya, perawatan pasien akan semakin lama dan menimbulkan masalah finansial. Tujuan penelitian adalah mengetahui efektifitas aroma terapi lavender, relaksasi progresif dan guided imagery untuk menurunkan kecemasan pasien pre operatif. Desain penelitian yang digunakan adalah Quasi-experimental dengan rancangan Pre-post-test atau one group before and after. Populasi penelitian adalah pasien dewasa yang akan menjalani operasi bedah elektif di RSUD dr. H. Abdul Moeloek Provinsi Lampung. Perhitungan besar sampel yang diambil dengan menggunakan Sample Size Calculator For Designing Clinical Research untuk one group before after study untuk uji statistik paired $t$ test. Dengan menetapkan Alpha 0,01, Betha 0,100, Effect Size 0,500 dan Standar Deviasi 1,00 sehingga jumlah sampel yang digunakan yaitu sebesar 60 orang. Teknik sampling menggunakan metode simple random sampling. Hasil penelitian ini menyimpulkan aroma terapi lavender, relaksasi otot progresif dan guided imagery efektif menurunkan kecemasan pre operatif (rata-rata skor sebelum intervensi 7.67 (SD 7.890), skor sesudah intervensi 4.05 (SD 5.806)) dengan $\rho$-value 0.000. Peneliti menyarankan agar aromaterapi lavender, relaksasi progresif dan guided imagery dapat dijadikan standar intervensi kecemasan pasien pre operatif oleh perawat.

Kata kunci: Guide imagery, Lavender, Relaksasi, Kecemasan 
Pembedahan merupakan pengalaman unik perubahan terencana pada tubuh yang terdiri dari tiga fase: pre operatif, intraoperatif, dan pasca operatif (Kozier, Erb, Berman \& Snyder, 2011). Menurut Muttaqin dan Sari, (2009) prosedur pembedahan akan memberikan suatu reaksi emosional bagi pasien.

Kecemasan adalah kekhawatiran yang tidak jelas dan menyebar, yang berkaitan dengan perasaan tidak pasti dan tidak berdaya (Stuart, 2006, hlm. 144). Kecemasan adalah satu kondisi kegelisahan mental, keprihatinan, ketakutan, atau firasat atau perasaan putus asa karena ancaman yang akan terjadi atau ancaman antisipasi yang tidak dapat diidentifikasi terhadap diri sendiri atau terhadap hubungan yang bermakna (Kozier, 2011).

Keadaan cemas pasien akan berpengaruh kepada fungsi tubuh menjelang operasi. Kecemasan yang tinggi, dapat mempengaruhi fungsi fisiologis tubuh yang ditandai dengan adanya peningkatan frekuensi nadi dan respirasi, pergeseran tekanan darah dan suhu, relaksasi otot polos pada kandung kemih dan usus, kulit dingin dan lembab, peningkatan respirasi, dilatasi pupil, dan mulut kering. Kondisi ini sangat membahayakan kondisi pasien, sehingga dapat dibatalkan atau ditundanya suatu operasi. Akibat lainnya, lama perawatan pasien akan semakin lama dan menimbulkan masalah finansial. Maka, perawat harus mampu mengatasi kecemasan pada pasien, sehingga kecemasan tersebut dapat dikurangi secara efektif (Smeltzer \& Bare, 2002).

Data dari World Health Organization (WHO) pada tahun 2007, Amerika Serikat menganalisis data dari 35.539 klien operasi dirawat di unit perawatan intensif antara 1 Oktober 2003 sampai 30 September 2006, sebanyak 2.473 klien (7\%) mengalami kecemasan (Safitri, 2015). Di Indonesia prevalensi kecemasan diperkirakan berkisar 9\%$21 \%$ populasi umum.

Penelitian lain yang dilakukan oleh Mulyani (2008), menunjukkan yang mengalami kecemasan ringan $(52,5 \%)$ dan kecemasan sedang $(47,5 \%)$ dari 40 pasien klien rawat inap di ruang penyakit bedah dan non bedah. Penelitian Rahmayati dan Handayani (2017) menyimpulkan kecemasan yang muncul pada pasien pre operatif umumnya disebabkan oleh kekhawatiran akan tindakan pembiusan, suasana kamar operasi dengan berbagai peralatan, nyeri, risiko kecacatan atau kematian meskipun pasien telah diberikan penjelasan pada saat inform concent dan penandatanganan surat izin operasi.

Penatalaksanaan kecemasan terbagi menjadi farmakologi, pendekatan suportif dan psikoterapi. Dari beberapa penelitian didapat bahwa penatalakasaan non farmakologis dapat menurunkan kecemasan diantaranya: terapi musik (Ferawati, 2018), terapi relaksasi nafas dalam (Murwati dan Istiqomah, 2016), terapi imajinasi terbimbing (Sarsito, 2015) dan terapi humor (Deliyani, Majudin \& Adiningsih, 2016). Teknik relaksasi yang biasa digunakan adalah relaksasi otot (relaksasi otot progresif, rendam air hangat, tarik nafas dalam), relaksasi dengan imajinasi terbimbing, dan respon relaksasi dari Benson (Smeltzer \& Bare, 2002).

Pemberian informasi pre operatif merupakan prosedur rutin dan menjadi bagian dari standar prosedur operasional pasien pre operatif sehingga semua pasien yang akan dilakukan pembedahan wajib diberikan informasi dan diberi kesempatan meminta penjelasan sampai jelas oleh dokter penanggungjawab dengan disaksikan oleh perawat. Namun pada kenyataannya pada beberapa pasien, jika hanya pemberian informasi pre operatif saja belum mampu menghilangkan kecemasan pasien. Dengan data di atas diketahui bahwa beberapa penatalaksanaan kecemasan non farmakologis sudah pernah diteliti sebelumnya yang memiliki dampak positif berupa penurunan kecemasan, namun belum ditemukan terapi manakah yang paling efektif untuk menurunkan kecemasan diantara terapi-terapi tersebut. Oleh karena itu peneliti tertarik untuk melakukan penelitian lebih lanjut tentang pengaruh aroma terapi lavender, terapi relaksasi progresif, dan guided imagery terhadap penurunan kecemasan pasien pre operatif.

\section{METODE}

Desain yang akan digunakan dalam penelitian ini adalah desain Quasi-experimental dengan rancangan non equivalent control group. Pada penelitian ini responden penelitian akan dilakukan pengukuran tingkat kecemasan sebelum dan sesudah intervensi pada saat menjelang operasi. Desain penelitian ini menggambarkan sekelompok responden yang diberikan intervensi. Waktu penelitian berlangsung dari bulan Juni s.d September 2017. Penelitian ini dilakukan di RS Abdul Moeloek Provinsi Lampung. Populasi pada penelitian ini adalah semua pasien dewasa yang akan menjalani operasi bedah elektif di RSUD dr. H. Abdul Moeloek Provinsi Lampung pada Agustus s.d September 2017 dengan estimasi populasi berdasarkan data RSUD dr. H. Abdul Moeloek Provinsi Lampung adalah rata-rata 300 orang per 
bulan. Perhitungan besar sampel ditetapkan berdasarkan perhitungan dengan menggunakan Sample Size Calculator For Designing Clinical Research untuk one group before after study dari http://www.sample-size.net/sample-size-studypaired-t-test/ dengan menggunakan uji statistik paired t-test. Dengan menetapkan Alpha 0,01, Betha 0,100, Effect Size 0,500 dan Standar Deviasi 1,00 maka jumlah sampel untuk memenuhi asumsi uji statistik yang digunakan yaitu sebesar 60 orang. Teknik pengambilan sampel (sampling) yang digunakan pada penelitian ini menggunakan metode simple random sampling,Instrumen pengumpulan data yang digunakan pada penelitian ini adalah Beck's Anxiety Index(BAI) dari Bekc A.T, Epstein N., Brown., G.Stein, 1988 di https://www.gphealth.org/media/1087/anxiety.pdf.

HASIL

Tabel 1. Distribusi Responden Berdasarkan Jenis Kelamin

\begin{tabular}{lcc}
\hline \multicolumn{1}{c}{ Jenis Kelamin } & $\boldsymbol{f}$ & $\mathbf{\%}$ \\
\hline Laki-laki & 30 & 50 \\
\hline Perempuan & 30 & 65 \\
\hline Total & $\mathbf{6 0}$ & $\mathbf{1 0 0}$ \\
\hline
\end{tabular}

Berdasarkan hasil penelitian pada tabel 1 diketahui bahwa jumlah jenis kelamin laki-laki dan perempuan masing-masing sebanyak 30 orang (50\%).

\section{Tabel 2. Distribusi Responden berdasarkan} Pendidikan

\begin{tabular}{lrr}
\hline Pendidikan & \multicolumn{1}{l}{$\boldsymbol{f}$} & \multicolumn{1}{c}{$\%$} \\
\hline SD & 38 & 63.3 \\
\hline SMP & 2 & 3.3 \\
\hline SMA & 20 & 33.3 \\
\hline Total & $\mathbf{6 0}$ & $\mathbf{1 0 0}$ \\
\hline
\end{tabular}

Berdasarkan hasil penelitian pada tabel 2 diketahui bahwa jumlah pendidikan terbanyak adalah SD sebanyak 38 responden (63.3\%).
Tabel 3. Distribusi Responden Berdasarkan Umur danTanda-tanda Vital

\begin{tabular}{|c|c|c|c|}
\hline Uraian & Min-Max & Mean & $S D$ \\
\hline Umur & $15-84$ & 46.9 & 14.5 \\
\hline \multicolumn{4}{|l|}{$\begin{array}{l}\text { TD sebelum } \\
\text { intervensi }\end{array}$} \\
\hline - Sistole & $100-170$ & 124.5 & 15.3 \\
\hline - Diastole & 70-110 & 82.7 & 13.9 \\
\hline \multicolumn{4}{|l|}{$\begin{array}{l}\text { TD sesudah } \\
\text { intervensi }\end{array}$} \\
\hline - Sistole & $100-170$ & 124.4 & 13.6 \\
\hline - Diastole & $70-110$ & 82.2 & 8.5 \\
\hline $\begin{array}{l}\text { TD sebelum } \\
\text { operasi }\end{array}$ & $110-150$ & 123.5 & 8.4 \\
\hline $\begin{array}{l}\text { - Sistole } \\
\text { - Diastole }\end{array}$ & $70-100$ & 82.5 & 6.5 \\
\hline $\begin{array}{l}\text { Nadi sebelum } \\
\text { Intervensi }\end{array}$ & $68-96$ & 80.5 & 6.4 \\
\hline $\begin{array}{l}\text { Nadi sesudah } \\
\text { Intervensi }\end{array}$ & $65-83$ & 80.7 & 4.5 \\
\hline $\begin{array}{l}\text { Nadi sebelum } \\
\text { Operasi }\end{array}$ & $75-92$ & 81.8 & 3.7 \\
\hline $\begin{array}{l}\text { Pernafasan } \\
\text { sebelum } \\
\text { Intervensi }\end{array}$ & $18-24$ & 20.4 & 1.7 \\
\hline $\begin{array}{l}\text { Pernafasan } \\
\text { sesudah } \\
\text { Intervensi }\end{array}$ & $18-22$ & 20.3 & 1.2 \\
\hline $\begin{array}{l}\text { Pernafasan } \\
\text { sebelum Operasi }\end{array}$ & $18-24$ & 20.3 & 1.1 \\
\hline
\end{tabular}

Tabel 3 menunjukkan rata-rata umur respondon 46.95, rata-rata sistole sebelum intervensi 124.50 dengan rata-rata diastole 82.67, rata-rata sistole sesudah intervensi 124.42 dengan rata-rata diastole 82.17 , rata-rata sistole sebelum operasi 123.50 dengan diastole 82.50, rata-rata nadi sebelum intervensi 80.53 , rata-rata sesudah intervensi 80.68 , rata-rata sebelum operasi 81.85 , rata-rata pernafasan sebelum intervensi 20.40, rata-rata sesudah intervensi 20.30 , dan rata-rata sebelum operasi adalah 20.32 .

Tabel 4. Distribusi Skor Kecemasan Responden

\begin{tabular}{lccc}
\hline Uraian & Min-Max & Mean & SD \\
\hline $\begin{array}{l}\text { Skor Sebelum } \\
\text { Intervensi }\end{array}$ & $0-37$ & 7.67 & 7.9 \\
\hline $\begin{array}{l}\text { Skor Sesudah } \\
\text { Intervensi }\end{array}$ & $0-30$ & 4.05 & 5.8 \\
\hline $\begin{array}{l}\text { Skor Sebelum } \\
\text { Operasi }\end{array}$ & $0-28$ & 4.20 & 5.1 \\
\hline
\end{tabular}

Berdasarkan hasil penelitian pada tabel 4 diketahui rata-rata skor sebelum intervensi 7.67, skor sesudah intervensi 4.05 dan skor sebelum operasi 4.20. 
Tabel 5. Hasil Uji Analisis Skor Sebelum Intervensi dan Sesudah Intervensi

\begin{tabular}{lcccc}
\hline Variabel & Mean & $\begin{array}{c}\text { Standar } \\
\text { Deviasi }\end{array}$ & n & $\begin{array}{c}p- \\
\text { value }\end{array}$ \\
\hline $\begin{array}{l}\text { Skor } \\
\begin{array}{l}\text { Sebelum } \\
\text { Intervensi }\end{array}\end{array}$ & 7.67 & 7.89 & 60 & \\
\hline $\begin{array}{l}\text { Skor } \\
\begin{array}{l}\text { Sesudah } \\
\text { Intervensi }\end{array}\end{array}$ & 4.05 & 5.81 & 60 & \\
\hline
\end{tabular}

Tabel 5 menunjukkan rata-rata skor sebelum intervensi 7.67 dengan standar devisasi 7.890 dan skor sesudah intervensi 4.05 dengan standar devisasi 5.806. Analisis uji dengan paired simples T-test didapatkan hasil $\rho$-value 0.000 maka dapat disimpulkan bahwa hasil bermakna.

Tabel 6. Hasil Uji Analisis Skor Sebelum Intervensi dengan Sebelum Operasi

\begin{tabular}{lcccc}
\hline Variabel & Mean & S D & n & pval \\
\hline $\begin{array}{l}\text { Skor } \\
\begin{array}{l}\text { Sebelum } \\
\text { Intervensi }\end{array}\end{array}$ & 7.67 & 7.89 & 60 & \\
\cline { 1 - 2 } $\begin{array}{l}\text { Skor } \\
\text { Sebelum } \\
\text { Operasi }\end{array}$ & 4.20 & 5.14 & 60 & $\mathbf{. 0 0 0}$ \\
\hline
\end{tabular}

Tabel 6 menunjukkan rata-rata skor sebelum intervensi 7.67 dengan standar devisasi 7.890 dan rata-rata sebelum operasi 4.20 dengan standar devisasi 5.141. Analisis uji dengan paired simples T-test didapatkan hasil $\rho$-value .787 maka dapat disimpulkan bahwa hasil tidak bermakna.

\section{PEMBAHASAN}

Hasil analisis data rata-rata skor kecemasan sebelum intervensi 7.67, skor sebelum operasi 4.20. Hal ini menunjukkan adanya penurunan rata-rata skor kecemasan. Kecemasan adalah gangguan alam perasaan yang ditandai dengan perasaan ketakutan atau kekhawatiran yang mendalam dan berkelanjutan, tidak mengalami gangguan dalam menilai kenyataan, kepribadian masih tetap utuh atau tidak mengalami keretakan kepribadian normal (Hawari, 2001).

Operasi atau tindakan medis pada umumnya menimbulkan rasa takut pada pasien. Kecemasan pre-operatif secara umum akan dialami oleh pasien setelah mengetahui dirinya dijadwalkan untuk menjalani prosedur pembiusan atau prosedur bedah dan akan terus meningkat sampai saat masuk rumah sakit.
Tingkat pendidikan, jenis kelamin dan umur pasien juga mempengaruhi kecemasan yang dialami pasien sebelum tindakan operasi. Pada penelitian ini sebagian besar tingkat pendidikan responden adalah SD sebanyak 38 responden (63.3\%), jumlah jenis kelamin laki-laki dan perempuan masing-masing sebanyak 30 orang $(50 \%)$ dan umur responden yang paling tua adalah 84 tahun. Dari hasil penelitian sebagian besar responden yang didapat merupakan responden yang tingkat pendidikannya rendah sehingga akan mempengaruhi responden dalam memahami terapi yang akan diberikan.

Setelah diberikan terapi, terjadi penurunan rata-rata skor kecemasan sebelum intervensi 7.67 menjadi 4.20. Secara kuantitatif penurunan ini bermakna karena menunjukkan adanya perbedaan skor sebelum intervensi dan sebelum operasi. Dalam parameter penunjang seperti tanda-tanda vital mengalami penurunan, rata-rata tekanan darah sebelum intervensi 124.50/ 82.67 mmHg menjadi $123.50 / 82.50 \mathrm{mmHg}$ dan ratarata pernapasan sebelum intervensi 20,40x/menit menjadi 20,32x/menit. Sedangkan pada nilai ratarata nadi, tidak mengalami penurunan yaitu ratarata nadi sebelum intervensi $80,53 \mathrm{x} /$ menit menjadi $81,85 x /$ menit.

Hasil analisis data rata-rata skor sebelum intervensi 7.67 dengan standar deviasi 7.890 dan skor sesudah intervensi 4.05 dengan standar deviasi 5.806 kemudian hasil analisis uji dengan menggunakan paired simples T-test didapatkan hasil $\rho$-value 0.000 maka dapat disimpulkan bahwa adanya pengaruh dari pemberian intervensi yang dilakukan, hal ini mungkin disebabkan oleh aromaterapi lavender yang dihirup oleh responden melalui hidung yang kontak langsung dengan bagian-bagian otak yang bertugas merangsang terbentuknya efek yang ditimbulkan oleh minyak atsiri. Hidung sendiri bukanlah organ yang membau, tetapi hanya memodifikasi suhu dan kelembaban udara yang masuk serta mengumpulkan benda asing yang mungkin ikut terhisap. Saraf otak pertama bertanggung jawab terhadap indera pembau dan menyampaikannya pada sel-sel reseptor. Ketika aroma lavender dihirup, molekul yang mudah menguap dari minyak tersebut dibawa oleh arus udara ke "atap" hidung dimana silia-silia yang lembut muncul dari sel-sel reseptor. Ketika molekul-molekul itu menempel pada rambutrambut tersebut, suatu pesan elektrokimia akan ditransmisikan melalui bola dan saluran olfactory ke dalam sistem limbik. Hal ini akan merangsang memori dan respon emosional responden dimana diikuti dengan audio responden yang secara tidak 
langsung mengikuti perintah untuk melakukan teknik relaksasi progresif.

Teknik relaksasi progresif dapat digunakan untuk mengurangi kecemasan,karena dapat menekan saraf simpatis sehingga mengurangi rasa tegang yang dialami oleh individu secara timbal balik, sehingga timbul counter conditioning (penghilangan). Relaksasi diciptakan setelah mempelajari sistem kerja saraf manusia, yang terdiri dari sistem saraf pusat dan sistem saraf otonom. Sistem saraf otonom ini terdiri dari dua subsistem yaitu sistem saraf simpatis dan sistem saraf parasimpatis yang kerjanya saling berlawanan. Sistem saraf simpatis lebih banyak aktif ketika tubuh membutuhkan energi misalnya pada saat terkejut, takut, cemas atau berada dalam keadaan tegang. Pada kondisi seperti ini, sistem saraf akan memacu aliran darah ke otot-otot skeletal, meningkatkan detak jantung, kadar gula dan ketegangan menyebabkan serabut-serabut otot kontraksi, mengecil dan menciut. Sebaliknya, relaksasi otot berjalan bersamaan dengan respon otonom dari saraf parasimpatis. Sistem saraf parasimpatis mengontrol aktivitas yang berlangsung selama penenangan tubuh, misalnya penurunan denyut jantung setelah fase ketegangan dan menaikkan aliran darah ke sistem gastrointestinal sehingga kecemasan akan berkurang dengan dilakukannya relaksasi progresif.

Selain pemberian terapi lavender dan relaksi otot progresif, penelitian ini juga menggunakan terapi guide imagery, dimana terapi guide imagery ini menggunakan pikiran responden dengan menggerakkan tubuh untuk berfikir menyembuhkan diri dan memelihara kesehatan atau rileks melalui komunikasi dalam tubuh melibatkan semua indra meliputi sentuhan, penciuman, penglihatan, dan pendengaran (Potter \& Perry, 2005). Hasil penelitian menunjukkan adanya penurunan skor kecemasan dengan pemberian aromaterapi lavender, relaksi progresif dan terapi guide imagery, hal ini mungkin terjadi dikarenakan selain indra penciuman yang telah

\section{DAFTAR PUSTAKA}

Beck, A. T., Epstein, N., Brown, G., \& Steer, R. A. 1988. An inventory for measuring clinical anxiety: psychometric properties. Journal of consulting and clinical psychology, 56(6), 893.

Deliyani, N. L., Mahajudin, M. S., \& Adiningsih, S. 2016. Efektivitas Terapi Humor dengan Media Film Komedi untuk Menurunkan Tingkat Kecemasan pada Lansia. Hospital memberikan rangsangan memori dan respon emosional, responden secara alami mengikuti perintah dengan audio untuk melakukan teknik relaksasi progresif dan guide imagery. Gabungan 3 teknik ini membuat klien rileks secara pikiran dan fisik.

Analisis uji dengan paired simples T-test antara rata-rata skor sebelum intervensi dengan rata-rata skor sebelum operasi didapatkan hasil $\rho$ value .000 maka dapat disimpulkan bahwa hasil bermakna. Hasil uji statistik menemukan penurunan rata-rata skor sebelum intervensi dengan sebelum operasi yaitu 7.67 menjadi 4.20. Hal ini sejalan dengan yang disampaikan oleh Mansjoer, 2007 bahwa secara umum kecemasan pasien sehari sebelum tindakan medis operasi akan meningkat dan semakin meningkat sesaat menjelang tindakan medikoperasi. Namun hasil penelitian menunjukkan bahwa efek terapi yang diberikan mampu bertahan hingga pasien menjelang masuk kamar operasi.

\section{SIMPULAN}

Berdasarkan hasil analisis data dan pembahasan yang telah diuraikan sebelumnya, peneliti menyimpulkan bahwa aromaterapi lavender, relaksasi otot progresif dan guided imagery memiliki pengaruh bermakna terhadap penurunan skor kecemasan pasien pre operatif ( $\rho$ value 0.000) dan pengaruh tersebut mampu bertahan hingga responden akan memasuki kamar operasi ( $\rho$-value .000).

\section{SARAN}

Dengan demikian disarankan kepada perawat untuk menggunakan terapi ini sebagai tindakan keperawatan menurunkan kecemasan dan menetapkannya sebagai standar prosedur tindakan non farmakologi terhadap kecemasan di ruang rawat.
Majapahit, 7(2).

http://ejurnalp2m.poltekkesmajapahit.ac.id /index.php/HM/article/view/109 (Diakses pada 28 Desember 2016).

Ferawati, F., \& Amiyakun, S. 2018. Pengaruh Pemberian Terapi Musik terhadap Penurunan Kecemasan dan Tingkat Stress Mahasiswa Semester VII Ilmu Keperawatan Dalam Menghadapi Skripsi 
di Sekolah Tingg Ilmu Kesehatan Insan Cendekia Husada Bojonegoro. Jurnal Ilmu Kesehatan MAKIA, I(1).

Hawari, Dadang. 2001. Manajemen Stres Cemas dan Depresi. Jakarta: Balai Penerbit FKUI.

Kozier, et all. 2010. Buku Ajar Fundamental Keperawata: Konsep, Proses \& Praktik, Ed. 7, Vol 2. Jakarta: EGC.

Mulyani, S., Paramastri, I., Priyanto, M.A. 2008. Komunikasi dan Hubungan Terapeutik Perawatan-Klien terhadap Kecemasan Pra Bedah Mayor. Berita Kedokteran Masyarakat. 24, 151-155.

Muttaqin \& Sari. 2009. Asuhan Keperawatan Perioperatif Konsep, Proses Dan Aplikasi. Jakarta: Salemba Medika

Murwati dan Henik Istiqomah. 2015. Pengaruh Lama dan Frekuensi Massage Teraphi Ibu Nifas Terhadap Depresi Postpartum. Jurnal Terpadu Ilmu Kesehatan, Volume 4, Nomor 2, November 2015. http://jurnal.poltekkes-solo.ac.id. (Diakses pada 2 Desember 2016).

Potter \& Perry. 2005. Fundamental Of Nursing. Philadelphia: WB Saunders Co.

Rahmayati, E., \& Handayani, R. S. 2017. Perbedaan Pengaruh Terapi Psikoreligius dengan Terapi Musik Klasik terhadap
Kecemasan Pasien Pre Operatif di RSUD dr. H. Abdul Moeloek Provinsi Lampung. Jurnal Kesehatan, 8(2), 191198.

Safitri. 2015. Aplikasi Pemberian Informasi Pra Operasi Terhadap Tingkat Kecemasan Pada Asuhan Keperawatan Tn. K Dengan Pra Bedah Hernia Inguinalis Dextra Di Ruang Bedah Kantil I RSUD Karanganyar. [Karya Tulis Ilmiah]. Surakarta: Program Studi Keperawatan, Stikes Kusu Husada. http://stikeskusumahusada.ac.id/digilib/do wnload.php?id=1428 (Diakses pada 26 Desember 2016)

Sarsito, S., Abi Muhlisin, S. K. M., \& Kartinah, S. K. 2015. Pengaruh Guide Imagery Terhadap Tingkat Kecemasan Pasien Hemodialisa Di RS PKU Muhammadiyah Surakarta. [Doctoral dissertation]. Surakarta: Universitas Muhammadiyah Surakarta. http://eprints.ums.ac.id/34407/ (Diakses pada 28 Desember 2016).

Smeltzer, C.S. \& Bare, B.G. 2002. Buku Ajar Keperawatan Medikal Bedah Brunner and Suddart. Vol.1 Edisi 8. Jakarta:EGC.

Stuart, GW. 2007. Buku Saku Keperawatan Jiwa. Edisi V. Jakarta. 